\title{
Research on the Main Research Topic Teaching Model for Environment Art Design Major
}

\author{
Ding Liwei \\ Associate Professor \\ Dean of Teaching and Research Office in Environment Art Design \\ Art College of Shangdong Women's University \\ Shangdong 250300 China
}

\begin{abstract}
The cultivating objectives of the Environment Art Design Major are the application competence of social practice and designing ability for environment design. The expert teaching models are confronting with the new challenges for many years and the original teaching model cannot suit for the requirements of the development of the market. To seek for a new teaching model that adapts to the social development and conforms to the sustainable development of the Environment Art Design major is extremely urgent. The exploration of the Main Research Topic teaching model of The Environment Art Design major is of profound realistic significance for cultivating practical and applicable talents and improving the new teaching models of higher education.
\end{abstract}

Key words--- environment art design; Main Research Topic teaching model; application

\section{INTRODUCTION}

The Environment Art Design major takes the responsibility for cultivating talents with the application competence of social practice and the designing competence of environment design and has provided a large number of professional talents to the society for many years. With the deepening of the education and higher requirement of society, the teaching models of Environment Art Design major is confronted with new challenges and the original teaching models cannot meet the demands of social development, which requires our reflection of the teaching models and teaching efficiency of the existing Environment Art Design major and makes it urgent to find out a new teaching model that adapts to the social development and conforms to the sustainable development of Environment Art Design major.

II. Analysis of the present teaching situation of

\section{Environment Art Design major}

1. The traditional teaching model of Environment Art Design major

With the advancement of society and the development of times as well as the requirements of market, the traditional teaching model that the teachers preach and the students finish the homework is already out of date, which, of course, would produce adverse effects to the teaching. Firstly, the traditional teaching model that adapts the periodical teaching model will make the students have no profound understanding of what the teachers have said and there is no interaction between the students and teachers, which makes the knowledge maintain superficial. Secondly, the homework done in the class is with low quality. Since they have no deep understanding of the knowledge they acquire and have no initiatives and interests, they just do the homework causally or just imitate and lack of creativity, reality and practicality. They are detached with the society and have no application competence. Thirdly, this teaching model also has adverse influence on the teaching. There is no communication and exchange between the teachers and students. And what the teachers receive is non-innovative homework without realistic values. The teaching levels of the students cannot be tested, let alone the research results.

2. The importance of establishing the Main Research Topic Teaching model of Environment Art Design major Environment Art Design major has been always following the traditional teaching model which violates the training objectives for talents with creativity, practicality and operability, detaches from the aims that designing arts should serve the public and makes the students with low innovation ability for creation, low practicability, aging of professional knowledge, detachment from the market and low social utility. This kind of teaching model, however, cannot meet the requirements of society for the talents of Environment Art Design major, let alone the comprehensive designing talents for senior application. The talents cultivating model of Environment Art Design major should be designed according to the standards of society. The university should cultivate the kind of talents that the society needs. The university should provide the relevant teaching environment for the knowledge that the society 
needs and provide the relevant resources. When the society has new knowledge level, the expertise that the university teaches should also be adjusted instead of passive teaching. Besides, from a long run, the university should make the teaching and researching accumulation as the predictable teaching, make reserves for professional knowledge in advance so as to adapt to the requirements of society. Therefore, the teaching model of environment Art Design major should base on the requirements of the society, pay attention to the cultivation of the students' innovation, creativity and practicality, go out of the classroom, participate some of the cases of environment art designing project so as to really combine the theory with the practice, which makes the Major Research Topic the best teaching model for realizing such objective.

III. Explanations to the Main Research Topic Teaching model of Environment Art Design major

\section{Meaning of the Main Research Topic Teaching model}

When referring to the Main Research Topic Teaching model for the Environment Art Design major, it divides the curriculum system of the Environment Art Design major during the undergraduate years into six parts according to the its specialized features, and each part choose one course as the Main Research Topic of the whole term while other courses are distributed by the Main Research Topic so as to combine the advantages of the professional knowledge and form course groups and make the students finish the specific topic by systematic training within fixed time.

\section{The contents of the Main Research Topic Teaching model}

During the undergraduate years of Environment Art Design major, there are altogether more than 20 professional courses to be learned except public courses, which can be divided into six categories according to their properties, namely professional basic courses, home decorational courses, exhibiting designing courses, hotel-office courses, landscape garden courses and the final graduation project, and each category have about 3-4 courses. By combining the similar courses together, they have a curriculum group of Main Research Topic. The students can learn the same topic from easy to difficult progressively and have a good master of the professional knowledge. Concretely speaking, according to the features of Environment Art Design major and the principles of the Main Research Topic teaching model, the courses can be set as six main topics, namely professional basic research topic, home decorational research topic, exhibiting designing research topic, hotel-office research topic, landscape garden research topic and the final graduation research topic. There are six themes in the six topics, namely the Main Research Topic. All the courses are learned according to the main research topic and all the teaching cases and homework are around the main research topic. In fact, as a student of undergraduate, he can have a deep understanding of main course and can satisfactorily meet the demand of the society after graduation if only he can earnestly finish these six research topics.

\section{The reasons for setting up the Main Research Topic teaching model for Environment Art Design major}

The reasons for setting up the Main Research Topic teaching model lie in that: firstly, in the teaching of Environment Art Design major, the existing curriculum is set according to the professional basic courses to specialized courses and to the final graduation design, therefore, the professional basic courses are in the first half while the specialized courses are in the second half. During the specialized courses, the course will finished before the students have a good master the contents of curriculum due to the time limit, which makes the courses they learn superficial. Secondly, the Environment Art Design major pay much more attention to the graduation project which is the final report of the overall undergraduate years and university, teachers and students are pay special emphasis to it. However, the final project in most universities are in the last term when the students go for internship, hence they have no time to concentrate on the final project. Therefore, the graduation projects of most students are without careful attention and cannot reflect the real levels of the students. Thirdly, the Main Research Topic teaching model can save time. Since the teaching periods for the arts in most university should be controlled to around 2,800 periods according to the requirements of Ministry of Education, while the public basic courses take up about 800 periods, and the rest 2,000 courses will be divided by all the courses, hence making it insufficiency in some courses. Some courses will be ended when the students are just about to have some feelings and the knowledge cannot be deepened. By applying the main research topic in Environment Art Design major, it can avoid the wastes of the materials in professional courses, the tedium in the content, the plain professional knowledge and can set up the teaching models that conform to the specialties of the major. 


\section{The application of the Main Research Topic teaching model in the practical teaching}

By the Main Research Topic teaching model, it will strive to cultivate the students' creativity and ability of independent thinking, make the students learn something, proficient in something and achieve in something. The followings are the application of the Main Research Topic teaching model in the practical teaching.

\section{Main Research Topic for basic designing}

Main Research Topic for basic designing are the basic course for undergraduate years as well as the first part of the Main Research Topic, which will directly affect the quality of the future professional courses and graduation project. The Main Research Topic for basic designing mainly consists of: basic sketch, basic coloring, plane composition, color composition, three dimensional compositions etc. Basic sketch and basic coloring are the transition from high school to university as well as the changes from modeling thinking pattern to designing thinking pattern and the teaching in this period should pay attention to the establishment of designing concepts, clarify the direction and objectives of professional learning and establish good modeling thinking pattern. For example, ask the students to do some creative homework for the assignment and mainly ask them to do some innovative designing instead of asking them to cultivate their concrete modeling ability.

\section{Main Research Topic for home decorational designing}

Home decorational designing are the only curriculum design that takes the home decoration as its topic during the 4 undergraduate years which involves many professional basic course, such as principles for interior design, drawing and reading of architectural decoration etc. The main research topic for home decorational design should take the home decoration as the main designing course. For example, the curriculum should be arranged from principles for interior design which clarifies the professional category, features some basic designing theories and methods. And then it comes to the learning of drawing and reading of architectural decoration, which emphasize the understanding and drawing of the drawing of architectural decoration. The students are asked to read the drawing and learn the basic requirements in the decoration drawing which can make preparation for the decoration $\mathrm{CAD}$ in the following. The learning of materials for architectural decoration should be arranged afterwards, which mainly ask the students to learn the decoration material in the markets of decoration material and the construction site. The last one should be the main research topic for home decoration design which is the important course in the curriculum and it should be arranged as 70-100 periods. The students are asked to finish the homework, including the layout, bookbinding and printing etc according to the requirements of the graduation project.

\section{Main Research Topic of the space designing for} official tourism

The space designing for official tourism belongs to the public place design, which consists of the design for office, design for the exclusive shop in the shopping mall, the design for the hotel etc. This scope of this part is big and the contents are inconsistent, which requires the flexible application in the arrangement of curriculum. For example, the design for the exclusive shop in the shopping mall should be arranged within the curriculum system of exhibition design, which will be beneficial for the consistency of the knowledge. During the Main Research Topic of space designing for official tourism, the following should be paid special attention to, firstly, the teaching for the space design for official tourism should be linked with the concrete cases of project rather than breaking away from the practical teaching. The teaching of the students should main concentrate on the explanation of practical cases. The students should go the filed trip in the construction site, find out the difference between the theory and the practice and make solid foundation for the knowledge. Secondly, the students should be encouraged to participate the social programs and construction after finishing the tasks and applies more spare time to finish the task. Only by real contacting with the practical project, the study of the professional course will not be pedantic. Thirdly, the space designing for official tourism are the primary choice for the undergraduate students when doing their graduation project. The students should make full use of the study in this period and finish the orientation of the graduation project and the general designing, making market research and lay solid foundation for the graduation project.

\section{Main Research Topic for the graduation project}

The graduation project is one important part for the courses of Environment Art Design major, which are the overall master of the students for the professional study and the exhibition of the teaching achievements. Firstly, the main 
research topic for graduation project should be combined with the internship of the students. The graduation project for the undergraduate students often last for half a year, during which the students should finish the internship, thesis defense and so on. The university should arrange the graduation project in advance, make the schedule for graduation project, clarify the concrete time for primary stage, mid-check, finishing for the designing and the printing and exhibition, make the students go for internship together with their tasks and finish the graduation project during work. Secondly, the teachers should make concrete guidance for the main research topic in the previous stage, put forward their suggestions for graduation project and redesigning. Thirdly, the students should be encouraged to finish their graduation project by applying the convenience during internship and combining the project of designing and construction.

\section{Conclusion}

The exploration of main research topic for Environment Art Design major has profound realistic significance for cultivating practical and applicable talents and improving the new teaching models for higher education. The teaching models are diverse and the teachers are requested to modify the educational teaching models during practical teaching, exploring the teaching model that is most suitable for the cultivation of the talents in his major and make contributions for the educational career.

\section{Reference:}

[ 1]Zhang Yiman \& Zheng Shuyang et al, Data set for Interior designing, [M]Beijing: China Architecture \& Building Press, 1991

[ 2]Huang Yafeng, Research on the teaching for Environment Art Design major,[J], Journal of Tianzhong, 2000.

[ 3]China Academy of Art, Environment Art Design [M] Shanghai: Shanghai Book and Painting Press, 2004.

[ 4]Dong Qingtao, On the Cultivation of Practical Competence and Module Teaching for the Students of Designing major, [J]

Art Education Research, 2011 